\title{
Updating Genetics Polymorphisms of Non-Syndromic Clefts Lip-Palates
}

\author{
Amine Rafik, Sellama Nadifi \\ Laboratory of Genetics and Molecular Pathology, University Hassan II, Casablanca, Morocco \\ Email: aminerafik8@gmail.com
}

How to cite this paper: Rafik, A. and Nadifi, S. (2018) Updating Genetics Polymorphisms of Non-Syndromic Clefts Lip-Palates. American Journal of Molecular Biology, 8, 178-185.

https://doi.org/10.4236/ajmb.2018.83015

Received: June 2, 2018

Accepted: July 10, 2108

Published: July 13, 2108

Copyright (c) 2018 by authors and Scientific Research Publishing Inc. This work is licensed under the Creative Commons Attribution International License (CC BY 4.0).

http://creativecommons.org/licenses/by/4.0/

(c) (i) Open Access

\begin{abstract}
Introduction: Non-Syndromic Clefts Lip-Palates (NSCLP/CP) are most common congenital malformation in the world, with very important psychic and social impact. Formation of NSCLP/CP arises from the interaction of environmental and genetic factors. This paper provides a review of recent progress in defining the genetic causes of NSCLP. Methods: A literature review was conducted on the Medline data by searching for the following keywords: genes, non-syndromic cleft lip-palate, and genetics of clefts lip-palates, until January 2018. Results: Various genes are identified in different population and country, with the study using case parent's trio. The aim of this study contributes to review relative gene which has been identify in non-syndromic cleft lip and palate, and to help to have a better understanding of the inheritance pattern of this pathology and the prevention of genetic disease. Conclusion: Although three major genes have been confirmed, the genetic research is necessary to provide an understanding of the pathophysiology of the clefts lip-palates.
\end{abstract}

\section{Keywords}

Cleft Lip, Cleft Palate, Cleft Lip and/or Cleft Palate, Non-Syndromic, Genetics

\section{Introduction}

The non-syndromic clefts lip-Palates or palates isolated (NSCLP/CP) are considered the most frequent congenital malformation in the world [1]. The prevalence of NSCLP/CP is estimated at 1/600 of births worldwide [2] with the birth prevalence varying based on geographic origin; it is higher in African population and lowest in Caucasians (1/500 vs. 1/2500 births, respectively) [1]. These differences appear to persist even after migration, suggesting that they are mediated by genetic, rather than environmental factors [3] [4]. Researchers are presently 
working to identify the etiological variants in these novel loci for understanding developmental disorders that lead to NSCLP, and this knowledge should eventually result in improved prevention, treatment and prognosis.

The purpose of this literature review is to update the most frequently genes involved in the genesis of the NSCLP.

\section{Material and Methods}

A systematic literature search was conducted using electronic databases of the Medline data by searching for the following keywords: "cleft palate", "facial cleft", "Genetic", "cleft lip", and "non-syndromic". In addition, a combination of the following terms was also used: "Genetic cleft lip palate", "Genetic cleft lip palate" and "non-syndromic".

For the keyword: Genetics cleft lip palate, we found 1908 items (January 2018) speaking of location, size, and function of the genome responsible. Among these 1908 articles, only 30 articles speak about genetic complex of the NSCLP.

\section{Results}

In this review, we describe the genes and phenotypes associated, and identifying a genomic locus. These are described in detail below and summarized in Table 1.

\section{Discussion}

Craniofacial development is very complex with a wide range of genes involved, combined with the influence of environmental factors. Progress towards the

Table 1. Summarized genotypes of NSCLP/CP founded in literature review.

\begin{tabular}{|c|c|c|c|}
\hline GENES & NAME & LOCUS & REFERENCES \\
\hline \multirow{3}{*}{ CONFIRMES } & IRF6 & $1 q 32-3 q 41$ & [5] [6] [7] \\
\hline & VAX1 & $10 \mathrm{q} 25$ & [8] [9] \\
\hline & MYC & $8 \mathrm{q} 24$ & [6] [10] \\
\hline \multirow{12}{*}{ UNDER STUDY } & $\mathrm{ABCA} 4$ & $1 \mathrm{p} 22.1$ & {$[10]$} \\
\hline & MTHFR & $1 \mathrm{p} 36.312$ & [11] [12] [3] \\
\hline & MSX1 & $4 \mathrm{p} 16.2$ & [13] [14] \\
\hline & TGFA & $2 \mathrm{p} 13$ & {$[15]$} \\
\hline & GADD45G & $9 \mathrm{q} 22.2$ & [16] \\
\hline & FOXE1 & $9 \mathrm{q} 22.33$ & [17] [18] \\
\hline & TMP1 & $15 \mathrm{q} 22.2$ & [17] \\
\hline & MAFB & $20 \mathrm{q} 12$ & [17] [19] \\
\hline & SUMO1 & $2 \mathrm{q} 33$ & [20] [21] \\
\hline & PVRL1 & $11 \mathrm{q} 23.3$ & [22] [23] [24] \\
\hline & TGFB3 & $14 q 24$ & [25] [26] \\
\hline & PDGFC & $4 q 32$ & [27] [28] \\
\hline
\end{tabular}


definition of genetic variation underlying NSCLP using gene discovery techniques including wide linking genome mapping association and candidate gene approaches. The identification of key genes in the genesis of NSCLP/CP represents a major challenge. A recently published meta-analysis of the two broad GWAS (genome wide association study) studies on NSCLP identified six unknown regions of significant susceptibility [29]. This study increased the number of loci responsible for NSCLP/CP to twelve. Thus, we will treat in this sub-section the most frequently locus incriminated in the genesis of this malformation reported by Beaty et al. [29]. These include IRF6, MSX1, MHTFR and TFG A.

\subsection{The Interferon Regulatory Factor 6 Encoding Gene (IRF6)}

The Interferon Regulatory factor 6 (IRF6) gene is located on the long arm (q) of chromosome 1, between positions 32.3 and 41 . Specifically, the IRF6 gene is found on base pairs 209, 785, 623 and base pairs 209, 806, 175 of chromosome 1 . It is produce a protein playing an important role in early development. This protein is a transcription factor, which means that it attaches to specific regions of DNA control and helps control the activity of certain genes. The Interferon Regulatory factor 6 (IRF6) was the first founded factor involved in the two autosomal dominant syndromes in clefts lip-palate Vander Wood syndrome (VWS) and pterygium popliteal syndrome (PPS) [30]. This led to the hypothesis that IRF6 is likely to contribute to the etiology of CLP/CP, confirmed by the research of Zucchero et al., involving several populations and subsequently resumed in both broad GWAS meta-analysis [31].

\subsection{The Methylenetetrahydrofolate Reductase Gene (MHTFR)}

Determining factors of genetic risk of NSCLP/CP has been the subject of numerous studies. It would then be possible that the variants of the genes involved in the pathway of folic acid metabolism could be associated with these risks. Among the genes involved in folic acid metabolism, is the MTHFR gene, and which has been most commonly associated with NSCLP/CP [32]. It produces an enzyme that catalyzes the methylation of the amino acid from homocysteine to methionine. Any defect on this route may result in methionine deficiency and an accumulation of homocysteine. In addition to the fundamental role of methionine as an important precursor in the methylation process of DNA and RNA, there is still the elevation of the serum homocysteine level in favor of teratogenicity during embryogenesis [33].

The coding gene for MTHFR is located at 1p36.312 and composed of 11 exons [34]. Several associations have been reported between the polymorphisms of the MTHFR gene and the risk of NSCLP/CP [35]. However, the results were contradictory, as is the case in a study by Han et al. [36]. It has been proved that the MTHFR gene would have a protective role rather than being a predisposing factor for NSCLP [36]. 


\subsection{The Growth Foctor Alpha Encoding Gene (TGFA)}

The gene encoding TFGA weighs 70 to 100 kilobases $(\mathrm{kb})$, is located on the short arm of chromosome 2 (2p13) encoding a polypeptide of 50 amino acids [37]. This protein binds to the epidermal growth factor receptor (EGFR) and is located at the epithelium of the mouth during the closure of the palate [38].

An experimental study in the murine model without EGF [39] showed an increase in the incidence of CLP/CP. This study concluded that NSCLP/CP may have a genetic relationship with TGFA polymorphisms. On the other hand, Mann, Luetteke, et al. [40] reported that the mutant mice of the TGFA gene had damage to the skin, hair and eyes but not to the lip or palate. Case-control studies and triad cases in humans have reported contradictory results. Although several etiologic studies have emphasized that NSCLP/CP is associated with allelic variations of TGFA [41].

\subsection{The Muscle Segment Homeobox 1 Gene (MSX1)}

The MSX1 gene produces a protein that regulates the activity of other genes. The MSX1 gene belongs to a large family of homeobox genes that act at the onset of development to control craniofacial morphogenesis during tooth development.

The MSX1 gene corresponds to the locus 4p16.1 and extends over $4.05 \mathrm{~kb}$. It contains two exons and one intron. MSX1 gene expression is associated with the D1 regulatory cycle, thus it inhibits cell differentiation. In homozygous transgenic animals, deficient in the MSX1 gene develop a cleft palate; show the failure of the development of the incisor as well as the stoppage of molar development [42]. In humans, the mutation of MSX1 showed an autosomal dominant form in dental agenesis [43]. Recently, a broad sequence analysis of MSX1 in 917 patients with CLP/CP identified mutations in 16 patients with a cleft lip with or without cleft palate or cleft palate alone, proving that this gene could be involved in both forms of cleft. The authors estimate that MSX1 mutations are responsible for only $2.2 \%$ in all NSCLP cases. A recent study has shown that the combined genetic study of rare variants of TGFA and MSX1 may increase the risk of cleft palate up to ten times, demonstrating the importance of gene-gene interactions in the etiology of NSCLP [44].

\section{Conclusion}

Understanding the genetic complex of NSCLP/CP allows for better preventive and clinical management by controlling risk factors and providing more accurate genetic counseling.

\section{References}

[1] Gundlach, K.K. and Christina, M. (2006) Epidemiological Studies on the Frequency of Clefts in Europe and World-Wide. Journal of Cranio-Maxillofacial Surgery, 34, 1-2. https://doi.org/10.1016/S1010-5182(06)60001-2

[2] Moosey, P. and Little, J. (2002) Epidemiology of Oral Clefts: An International Perspective. In: Wyszynski, D.F., Ed., Cleft Lip and Palate: From Origin to Treatment, 
Oxford University Press, Oxford, 128.

[3] Bezerra, J.F., Oliveira, G.H., Soares, C.D., Cardoso, M.L., Ururahy, M.A., Neto, F.P., et al. (2015) Genetic and Non-Genetic Factors That Increase the Risk of Non-Syndromic Cleft Lip and/or Palate Development. Oral Diseases, 21, 393-399. https://www.ncbi.nlm.nih.gov/pubmed/25219684

[4] Dixon, M.J., Marazita, M.L., Beaty, T.H. and Murray, J.C. (2011) Cleft Lip and Palate: Understanding Genetic and Environmental Influences. Nature Reviews Genetics, 12, 167-178. https://www.ncbi.nlm.nih.gov/pubmed/21331089

[5] Rahimov, F., Marazita, M.L., Visel, A., Cooper, M.E., Hitchler, M.J., Rubini, M., et al. (2008) Disruption of an AP-2 $\alpha$ Binding Site in an IRF6 Enhancer Is Associated with Cleft Lip. Nature Genetics, 40, 1341-1347.

https://www.nature.com/articles/ng.242

https://doi.org/10.1038/ng.242

[6] Birnbaum, S., Ludwig, K.U., Reutter, H., Herms, S., Steffens, M., Rubini, M., et al. (2009) Key Susceptibility Locus for Nonsyndromic Cleft Lip with or without Cleft Palate on Chromosome 8q24. Nature Genetics, 41, 473-477.

https://www.nature.com/articles/ng.333

https://doi.org/10.1038/ng.333

[7] Zucchero, T.M., Cooper, M.E., Maher, B.S., Daack-Hirsch, S., Nepomuceno, B., Ribeiro, L., et al. (2004) Interferon Regulatory Factor 6 (IRF6) Gene Variants and the Risk of Isolated Cleft Lip or Palate. New England Journal of Medicine, 351, 769-780. https://www.nejm.org/doi/full/10.1056/NEJMoa032909 https://doi.org/10.1056/NEJMoa032909

[8] Mangold, E., Ludwig, K.U., Birnbaum, S., Baluardo, C., Ferrian, M., Herms, S., et al. (2010) Genome-Wide Association Study Identifies Two Susceptibility Loci for Nonsyndromic Cleft Lip with or without Cleft Palate. Nature Genetics, 42, 24-26. https://www.nature.com/articles/ng.506 https://doi.org/10.1038/ng.506

[9] Beaty, T.H., Murray, J.C., Marazita, M.L., Munger, R.G., Ruczinski, I., Hetmanski, J.B., et al. (2010) A Genome-Wide Association Study of Cleft Lip with and without Cleft Palate Identifies Risk Variants near $M A F B$ and $A B C A 4$. Nature Genetics, 42, 525-529. https://www.nature.com/articles/ng.580 https://doi.org/10.1038/ng.580

[10] Barrett, J.C., Clayton, D.G., Concannon, P., Akolkar, B., Cooper, J.D., Erlich, H.A., et al. (2009) Genome-Wide Association Study and Meta-Analysis Find That over 40 Loci Affect Risk of Type 1 Diabetes. Nature Genetics, 41, 703-707.

https://www.nature.com/articles/ng.381

https://doi.org/10.1038/ng.381

[11] Mills, J.L., Molloy, A.M., Parle-McDermott, A., Troendle, J.F., Brody, L.C., Conley, M.R., et al. (2008) Folate-Related Gene Polymorphisms as Risk Factors for Cleft Lip and Cleft Palate. Birth Defects Research Part A: Clinical and Molecular Teratology, 82, 636-643. http://onlinelibrary.wiley.com/doi/10.1002/bdra.20491/full

[12] Jagomägi, T., Nikopensius, T., Krjutškov, K., Tammekivi, V., Viltrop, T., Saag, M., et al. (2010) MTHFR and MSX1 Contribute to the Risk of Nonsyndromic Cleft Lip/Palate. European Journal of Oral Sciences, 118, 213-220.

http://onlinelibrary.wiley.com/doi/10.1111/j.1600-0722.2010.00729.x/full https://doi.org/10.1111/j.1600-0722.2010.00729.x

[13] Jezewski, P., Vieira, A., Nishimura, C., Ludwig, B., Johnson, M., O’brien, S., et al. (2003) Complete Sequencing Shows a Role for $M S X 1$ in Non-Syndromic Cleft Lip 
and Palate. Journal of Medical Genetics, 40, 399-407.

http://jmg.bmj.com/content/40/6/399.short

[14] van den Boogaard, M.-J.H., Dorland, M., Beemer, F.A. and van Amstel, H.K.P. (2000) MSX1 Mutation Is Associated with Orofacial Clefting and Tooth Agenesis in Humans. Nature Genetics, 24, 342-343.

https://www.nature.com/articles/ng0400_342

[15] Ardinger, H., Buetow, K., Bell, G.I., Bardach, J., VanDemark, D. and Murray, J. (1989) Association of Genetic Variation of the Transforming Growth Factor-Alpha Gene with Cleft Lip and Palate. American Journal of Human Genetics, 45, 348-353. https://www.ncbi.nlm.nih.gov/pmc/articles/PMC1683414/

[16] Goff, S.A., Ricke, D., Lan, T.-H., Presting, G., Wang, R., Dunn, M., et al. (2002) A Draft Sequence of the Rice Genome (Oryza sativa L. ssp. japonica). Science, 296, 92-100. http://science.sciencemag.org/content/296/5565/92 https://doi.org/10.1126/science.1068275

[17] Beaty, T., Taub, M.A., Scott, A.F., Murray, J., Marazita, M., Schwender, H., et al. (2013) Confirming Genes Influencing Risk to Cleft Lip with/without Cleft Palate in a Case-Parent Trio Study. Human Genetics, 132, 771-781.

https://link.springer.com/article/10.1007/s00439-013-1283-6 https://doi.org/10.1007/s00439-013-1283-6

[18] Setó-Salvia, N. and Stanier, P. (2014) Genetics of Cleft Lip and/or Cleft Palate: Association with Other Common Anomalies. European Journal of Medical Genetics, 57, 381-393. https://www.sciencedirect.com/science/article/pii/S1769721214000883

[19] Leslie, E.J. and Marazita, M.L. (2013) Genetics of Cleft Lip and Cleft Palate. American Journal of Medical Genetics Part C: Seminars in Medical Genetics, 163, 246-258. http://onlinelibrary.wiley.com/doi/10.1002/ajmg.c.31381/full

[20] Alkuraya, F.S., Saadi, I., Lund, J.J., Turbe-Doan, A., Morton, C.C. and Maas, R.L. (2006) SUM01 Haploinsufficiency Leads to Cleft Lip and Palate. Science, 313, 1751. http://science.sciencemag.org/content/313/5794/1751.short

[21] Shi, M., Mostowska, A., Jugessur, A., Johnson, M.K., Mansilla, M.A., Christensen, K., et al. (2009) Identification of Microdeletions in Candidate Genes for Cleft Lip and/or Palate. Birth Defects Research Part A: Clinical and Molecular Teratology, 85, 42-51. http://onlinelibrary.wiley.com/doi/10.1002/bdra.20571/full

[22] Sözen, M.A., Suzuki, K., Tolarova, M.M., Bustos, T., Iglesias, J.E.F. and Spritz, R.A. (2001) Mutation of PVRL1 Is Associated with Sporadic, Non-Syndromic Cleft Lip/Palate in Northern Venezuela. Nature Genetics, 29, 141-142. https://www.nature.com/articles/ng740

[23] Sözen, M.A., Hecht, J.T. and Spritz, R.A. (2009) Mutation Analysis of the PVRL1 Gene in Caucasians with Nonsyndromic Cleft Lip/Palate. Genetic Testing and Molecular Biomarkers, 13, 617-621. http://online.liebertpub.com/doi/abs/10.1089/gtmb.2009.0052

[24] Avila, J.R., Jezewski, P.A., Vieira, A.R., Orioli, I.M., Castilla, E.E., Christensen, K., et al. (2006) PVRL1 Variants Contribute to Non-Syndromic Cleft Lip and Palate in Multiple Populations. American Journal of Medical Genetics Part A, 140A, 2562-2570. http://onlinelibrary.wiley.com/doi/10.1002/ajmg.a.31367/full

[25] Lidral, A.C., Romitti, P.A., Basart, A.M., Doetschman, T., Leysens, N.J., Daack-Hirsch, S., et al. (1998) Association of $M S X 1$ and TGFB3 with Nonsyndromic Clefting in Humans. The American Journal of Human Genetics, 63, 557-568. https://www.sciencedirect.com/science/article/pii/S0002929707615006 https://doi.org/10.1086/301956 
[26] Vieira, A., Orioli, I., Castilla, E., Cooper, M., Marazita, M. and Murray, J. (2003) $M S X 1$ and TGFB3 Contribute to Clefting in South America. Journal of Dental Research, 82, 289-292.

http://journals.sagepub.com/doi/abs/10.1177/154405910308200409

[27] Ding, H., Wu, X., Boström, H., Kim, I., Wong, N., Tsoi, B., et al. (2004) A Specific Requirement for PDGF-C in Palate Formation and PDGFR- $\alpha$ Signaling. Nature Genetics, 36, 1111-1116. https://www.nature.com/articles/ng1415

[28] Choi, S.J., Marazita, M.L., Hart, P.S., Sulima, P.P., Field, L.L., McHenry, T.G., et al. (2009) The PDGF-C Regulatory Region SNP rs28999109 Decreases Promoter Transcriptional Activity and Is Associated with CL/P. European Journal of Human Genetics, 17, 774-784. https://www.nature.com/articles/ejhg2008245

[29] Ludwig, K.U., Mangold, E., Herms, S., Nowak, S., Reutter, H., Paul, A., et al. (2012) Genome-Wide Meta-Analyses of Nonsyndromic Cleft Lip with or without Cleft $\mathrm{Pa}$ late Identify Six New Risk Loci. Nature Genetics, 44, 968-971. https://www.nature.com/articles/ng.2360

[30] Scapoli, L., Palmieri, A., Martinelli, M., Pezzetti, F., Carinci, P., Tognon, M., et al. (2005) Strong Evidence of Linkage Disequilibrium between Polymorphisms at the IRF6 Locus and Nonsyndromic Cleft Lip with or without Cleft Palate, in an Italian Population. The American Journal of Human Genetics, 76, 180-183.

https://www.sciencedirect.com/science/article/pii/S0002929707625567 https://doi.org/10.1086/427344

[31] Grant, S.F., Wang, K., Zhang, H., Glaberson, W., Annaiah, K., Kim, C.E., et al. (2009) A Genome-Wide Association Study Identifies a Locus for Nonsyndromic Cleft Lip with or without Cleft Palate on 8q24. The Journal of Pediatrics, 155, 909-913. https://www.jpeds.com/article/S0022-3476(09)00575-7/fulltext

[32] Pan, Y., Zhang, W., Ma, J., Du, Y., Li, D., Cai, Q., et al. (2012) Infants' MTHFR Polymorphisms and Nonsyndromic Orofacial Clefts Susceptibility: A Meta-Analysis Based on 17 Case-Control Studies. American Journal of Medical Genetics Part A, 158A, 2162-2169. http://onlinelibrary.wiley.com/doi/10.1002/ajmg.a.35503/full

[33] Greene, N.D., Dunlevy, L.P. and Copp, A.J. (2003) Homocysteine Is Embryotoxic but Does Not Cause Neural Tube Defects in Mouse Embryos. Anatomy and Embryology, 206, 185-191. https://link.springer.com/article/10.1007/s00429-002-0284-3

[34] Reutter, H., Birnbaum, S., Lacava, A.D., Mende, M., Henschke, H., Bergé, S., et al. (2008) Family-Based Association Study of the MTHFR Polymorphism C677T in Patients with Nonsyndromic Cleft Lip and Palate from Central Europe. The Cleft Palate-Craniofacial Journal, 45, 267-271.

http://journals.sagepub.com/doi/abs/10.1597/06-174 https://doi.org/10.1597/06-174

[35] Bhaskar, L., Murthy, J. and Babu, G.V. (2011) Polymorphisms in Genes Involved in Folate Metabolism and Orofacial Clefts. Archives of Oral Biology, 56, 723-737. https://www.sciencedirect.com/science/article/pii/S0003996911000276 https://doi.org/10.1016/j.archoralbio.2011.01.007

[36] Han, Y., Pan, Y., Du, Y., Tong, N., Wang, M., Zhang, Z., et al. (2011) Methylenetetrahydrofolate Reductase C677T and A1298C Polymorphisms and Nonsyndromic Orofacial Clefts Susceptibility in a Southern Chinese Population. DNA and Cell Biology, 30, 1063-1068. http://online.liebertpub.com/doi/abs/10.1089/dna.2010.1185

[37] Vieira, A., Meira, R., Modesto, A. and Murray, J. (2004) MSX1, PAX9, and TGFA Contribute to Tooth Agenesis in Humans. Journal of Dental Research, 83, 723-727. 
http://journals.sagepub.com/doi/abs/10.1177/154405910408300913 https://doi.org/10.1177/154405910408300913

[38] Passos-Bueno, M.R., Gaspar, D.A., Kamiya, T., Tescarollo, G., Rabanéa, D., Richieri-Costa, A., et al. (2004) Transforming Growth Factor- $\alpha$ and Nonsyndromic Cleft Lip with or without Palate in Brazilian Patients: Results of a Large Case-Control Study. The Cleft Palate-Craniofacial Journal, 41, 387-391.

http://journals.sagepub.com/doi/abs/10.1597/03-054.1 https://doi.org/10.1597/03-054.1

[39] Martinelli, M., Scapoli, L., Pezzetti, F., Spinelli, G., Lunardi, S. and Carinci, F. (2009) Lack of Association between Common Polymorphisms of Epidermal Growth Factor Receptors and Nonsyndromic Cleft Lip with or without Cleft Palate. International Journal of Pediatric Otorhinolaryngology, 73, 929-931.

https://www.sciencedirect.com/science/article/pii/S0165587609000810 https://doi.org/10.1016/j.ijporl.2009.02.013

[40] Fowler, K.J., Mann, G.B. and Dunn, A.R. (1993) Linkage of the Murine Transforming Growth Factor $\alpha$ Gene with Igk, Ly-2, and Fabp1 on Chromosome 6. Genomics, 16, 782-784. https://www.sciencedirect.com/science/article/pii/S0888754383712681

[41] Feng, C., Zhang, E., Duan, W., Xu, Z., Zhang, Y. and Lu, L. (2014) Association between Polymorphism of TGFA Taq I and Cleft Lip and/or Palate: A Meta-Analysis. BMC Oral Health, 14, 88.

https://bmcoralhealth.biomedcentral.com/articles/10.1186/1472-6831-14-88 https://doi.org/10.1186/1472-6831-14-88

[42] Thomas, T., Kurihara, H., Yamagishi, H., Kurihara, Y., Yazaki, Y., Olson, E.N., et al. (1998) A Signaling Cascade Involving Endothelin-1, dHAND and msx1 Regulates Development of Neural-Crest-Derived Branchial Arch Mesenchyme. Development, 125, 3005-3014. http://dev.biologists.org/content/125/16/3005.short

[43] Vieira, A.R., Avila, J.R., Daack-Hirsch, S., Dragan, E., Félix, T.M., Rahimov, F., et al. (2005) Medical Sequencing of Candidate Genes for Nonsyndromic Cleft Lip and Palate. PLoS Genet, 1, e64.

http://journals.plos.org/plosgenetics/article?id=10.1371/journal.pgen.0010064

[44] Jugessur, A., Lie, R.T., Wilcox, A.J., Murray, J.C., Taylor, J.A., Saugstad, O.D., et al. (2003) Variants of Developmental Genes (TGFA, TGFB3, and MSX1) and Their Associations with Orofacial Clefts: A Case-Parent Triad Analysis. Genetic Epidemiology, 24, 230-239. http://onlinelibrary.wiley.com/doi/10.1002/gepi.10223/full 